\title{
ARTYKUŁY
}

Klio. Czasopismo poświęcone dziejom Polski i powszechnym

PL ISSN 1643-8191, t. 49 (2)/2019, s. 3-18

\section{(i) $\odot$}

\section{ALEKSANDER BOŁDYREW}

\section{Badania historyczno-wojskowe nad epoką Piastów i Jagiellonów}

\section{History of Warfare Studies on Piasts' and Jagiellons' Epoch}

Streszczenie. Niniejszy artykuł przedstawia uwagi i propozycje badawcze dotyczące badań historyczno-wojskowych nad epoką Piastów i Jagiellonów. Skupia się głównie na uwzględnieniu w badaniach obszarów dotąd marginalizowanych oraz wykorzystaniu niezbadanych dotychczas przekazów źródłowych. Zasugerowano również możliwość przygotowania kompleksowej monografii poświęconej dziejom wojskowym tego okresu.

Abstract. This work presents comments and proposals concerning Piasts' and Jagiellons' history of warfare studies. It shows the requirement of focusing on so far marginalised problems and analysis of unexamined sources. It also suggests possibility of preparing complex monograph of Piast's and Jagiellon's history of warfare.

Słowa kluczowe: średniowieczna i wczesnonowożytna historia wojskowości, Polska średniowieczna, Polska wczesnonowożytna.

Keywords: medieval and early modern history of warfare, medieval Poland, early modern Poland.

* Wydział Filozoficzno-Historyczny, Uniwersytet Łódzki, ul. A. Kamińskiego 27a, 90-219 Łódź, bow0@poczta.onet.pl, ORCID: 0000-0002-8626-9582. 
Celem niniejszego artykułu jest przedstawienie kilku uwag, refleksji i propozycji badawczych w zakresie badań historyczno-wojskowych nad epoką Piastów i Jagiellonów. Z uwagi na rozległość i złożoność omawianego okresu przedmiotem rozważań są tylko wybrane zagadnienia. $\mathrm{Na}$ przestrzeni ponad 500 lat dziejów wojskowości średniowiecznej i wczesnonowożytnej zaszły poważne przemiany struktury państwa, modelu władzy oraz liczne przeobrażenia gospodarcze, społeczne i kulturowe. Odnosząc się pokrótce do dorobku historiografii historyczno-wojskowej rezygnuję z jego pełnego omówienia, przekracza to bowiem możliwości przeglądowego studium. Uwzględnienie opublikowanych prac tylko polskich badaczy wypełniłoby bowiem pokaźny tom. Zestawienia bibliograficzne w przedmiotowym zakresie były już zresztą publikowane. Dla przykładu warto przypomnieć, że same bibliografie grunwaldzkie (Waldemara Mierzwy ${ }^{1}$ oraz Anity Romulewicz, Anny Wysockiej i Sylwi Białeckiej²) liczą w sumie około 250 stron, a dotyczą przecież jednej bitwy. W dalszej części artykułu zostaną więc przywołane głównie najnowsze opracowania oraz studia, które wyznaczały nowe obszary i perspektywy badawcze, a ich autorzy uwzględniali kwestie wcześniej marginalizowane bądź puentowane kilkoma zdaniami.

Zamiar ten wynika z założenia, że odbiorcy prac historyczno-wojskowych, a przy okazji reprezentanci nauk zajmujących się wojną z innej perspektywy teoretyczno-metodologicznej, podkreślają naddatek i niedobór studiów w pewnych obszarach. Punktem wyjścia do takiego twierdzenia jest założenie, że każda struktura, a zatem i struktura militarna, realizuje się w czterech obszarach. Pierwszym z nich jest tak zwana socjomasa, czyli liczba ludności, drugim - socjoenergia wyrażająca się we wskaźnikach ekonomicznych, trzecim - socjostruktura, a więc forma organizacji, ostatnim zaś socjokultura, czyli zespół wartości i celów socjomasy i socjostruktury. W przypadku historii wojskowości mielibyśmy więc do czynienia odpowiednio z liczebnością wojsk, szeroko rozumianymi środkami bojowymi, którymi dysponuje wojsko, organizacją siły zbroj-

${ }^{1}$ W. Mierzwa, Bibliografia grunwaldzka, Olsztyn 1990.

2 A. Romulewicz, A. Wysocka, S. Białecka, Bibliografia grunwaldzka za lata 1990-2010 , Olsztyn 2010. 
nej i ideowym podłożem działań zbrojnych, innymi słowy świadomością celów walki. Nierzadko historykom wojskowości zarzuca się nadmiar badań nad socjomasą wojska i jej siłą sprawczą w trakcie działań zbrojnych, a niedobór w zakresie pozostałych trzech czynników. Jak pisali autorzy zarysu filozofii bezpieczeństwa, „[...] nierzadko, analizy [...] absolutyzują element socjomasowy - liczbę żołnierzy. Tym samym często innych nie doceniają $[\ldots] "$...

Uważam, że pogląd ten jest nie do końca uprawniony, zważywszy zwłaszcza na wyniki najnowszych badań, zarówno w zakresie struktury, organizacji i sposobów finansowania wojska oraz jego uzbrojenia, jak i świadomości celów podejmowanej walki. Jednocześnie nie sposób nie zauważyć, że w przywołanym wyżej stwierdzeniu Janusza Świniarskiego i Włodzimierza Chojnackiego jest nieco racji. Należy się zgodzić, że historia wojskowości, jak każda dyscyplina nauki historycznej, przejawia utylitarny charakter swych ustaleń w połączeniu z innymi - pokrewnymi - dyscyplinami. Kwestie te są jednak bardziej złożone i wielopłaszczyznowe. Trzeba bowiem pamiętać, że dotychczasowe badania skupiały się głównie na problemie powiązania dziejów działań wojennych z wątkami politycznymi. Jest to zrozumiałe, zwłaszcza, iż jedno z praw walki zbrojnej wyraźnie formułuje zasadę, iż wojna jest narzędziem działalności politycznej (w ujęciu Carla von Clausewita: „Wojna jest niczym innym, jak dalszym ciągiem polityki przy użyciu innych środków) ${ }^{4}$. Idąc tym tropem, należy zaznaczyć, że opisom zmagań zbrojnych towarzyszyło poszanowanie zasady konstytuującej zależność przebiegu walki zbrojnej od stosunku potencjałów bojowych. Odnoszę jednak wrażenie, że zjawisko potencjału militarnego traktowano jako samodzielny byt, który de facto jest przecież jedynie emanacją potencjału gospodarczego strony wchodzącej w konflikt. Nawiązuję tu do kolejnego prawa walki zbrojnej, mówiącego o zależności sposobów i form prowadzenia sporu od materialnej podstawy, którą się dysponuje. W stwierdzeniu tym widzę nie tylko fizycznie istniejący zasób środków stricte bojowych oraz rezerwowych materiałów wojennych, którymi można dysponować w czasie konfrontacji, ale i zdolność do

3 J. Świniarski, W. Chojnacki, Filozofia bezpieczeństwa, Warszawa 2004, s. 26.

${ }^{4}$ C. von Clausewitz, O wojnie, tłum. A. Cichowicz, L. Koc, Kraków 2003, s. 468. 
wytwarzania tychże środków w trakcie trwania konfliktu. Innymi słowy istotne jest zwrócenie uwagi na potencjalną możliwość odtwarzania i rozbudowywania systemu - struktury wytwarzającej środki bojowe w czasie konfliktu.

Wiązanie działań zbrojnych z tłem politycznym jest oczywiste, lecz myślę, że wiązanie zjawiska wojny z podstawą gospodarczą państwa powinno być równie istotne. Zważywszy na specyfikę systemu gospodarczego państwa średniowiecznego i wczesnonowożytnego, gdzie rolnictwo było podstawową gałęzią gospodarki, nie można pomijać pewnych prawidłowości. I tak na przykład w gospodarce opartej na rolnictwie wypracowanie nadwyżki produkcyjnej trwa wiele sezonów, a należy pamiętać, że nie zawsze armia mogła korzystać z zasobów przeciwnika. Zjawisko to jest szczególnie widoczne w przypadku obrony przed najazdem, kiedy możliwości produkcyjne zawężają się, zaś zapasy przeznaczone dla wojska topnieją. Spożytkowanie tej nadwyżki na przeprowadzenie akcji militarnej w jednym roku pociąga za sobą określone konsekwencje dla kolejnych lat. Zatem nieuwzględnianie współzależności gospodarki i wojny jest swoistym deficytem, zubaża pole badawcze historyka wojskowości. Identyfikacja tego deficytu może pomóc w sformułowaniu postulatów badawczych i wypracowaniu strategii, pozwalających na podjęcie studiów z pogranicza historii wojskowości i dziejów gospodarki. Tego rodzaju studia otworzyłyby zupełnie nowe perspektywy badawcze. Jednocześnie należy pamiętać, że uzyskanie precyzyjnych danych dla tak odległego okresu może okazać się niemożliwe, a badacz często będzie skazany na szacunki dotyczące po pierwsze, liczby ludności zdolnej do uczestniczenia w procesie produkcyjnym, po drugie, efektywności ich działalności gospodarczej, po trzecie wreszcie liczebności siły zbrojnej, która teoretycznie nie powinna uszczuplać zasobu rąk zdolnych do pracy w trakcie wojny. Wzajemne relacje tych czynników mogły przecież stanowić o sukcesie lub porażce kampanii wojennej. Dość przywołać przykład wojny trzynastoletniej, w której jednym ze stale powracających wątków były braki finansowe stron prowadzących konflikt, czy to w przypadku wykupienia, a nie zdobycia zamku malborskiego, czy choćby opłacenia wojsk najemnych i zaciężnych. Przykład bitwy pod Świecinem, uznawanej za przełomową w latach wojny, najlepiej dowodzi znaczenia zgromadzonych funduszy. Jakże skromnie prezentowały się siły Piotra Du- 
nina oraz Fritza Rawenecka w zestawieniu z liczebnością kombatantów pod Grunwaldem 5 . Kiedy jednak armię tworzono w oparciu o zasady czysto finansowe, a nie w ramach obowiązku feudalnego, wynikającego między innymi z ius militare, sytuacja ulegała zmianie. Zresztą wojna trzynastoletnia sama w sobie może być traktowana jako moment przełomowy, w którym bitwy pod Chojnicami (1454 r.) i Świecinem (1462 r.) sygnalizują stopniową rezygnację z expeditio generalis jako podstawowej siły zbrojnej państwa i przejście do wojska pieniężnego (najemnego i zaciężnego), które zaczęło zastępować pospolite ruszenie. Oczywiście proces ten postępował przez kolejne dziesięciolecia i trudno wyznaczyć cezurę rozgraniczającą dwie epoki. Były to jednak zmiany zapoczątkowujące zupełnie nowy obyczaj militarny, zarówno jeśli chodzi o organizację i finansowanie wojska, jak również jego modus operandi. Zmiany te, trwające przynajmniej od 1462 roku, wprowadziły sukcesywnie wojsko polskie w epokę renesansu. Dotychczas jednak tradycyjna periodyzacja dziejów zamykająca średniowiecze w 1492 bądź 1505 roku rozdzielała pewien proces, który nie był odpowiednio widoczny. Stąd postulat rozpatrywania dziejów wojskowości i wojska w perspektywie panowania dynastii Piastów i Jagiellonów, a nie średniowiecza i wczesnej nowożytności odrębnie.

Jednocześnie nie trudno dostrzec, że zasób źródłowy dotyczący realiów średniowiecznych został nie tylko dobrze poznany, ale i opracowany. Oczywiście można i należy liczyć na odkrycie nowych przekazów źródłowych (na przykład w wyniku szeroko zakrojonej kwerendy archiwalnej prowadzonej w krajach sąsiednich), ale nawet jeśli dojdzie do tego, to skala takiego od-

${ }^{5}$ Liczebność wojsk polskich i litewskich pod Grunwaldem A. Nadolski szacuje na około 30 tys. kombatantów (20 tys. wojsk koronnych i 10 tys. wojsk litewskich), natomiast liczebność armii krzyżackiej została przez niego oszacowana na około 15 tys., zob. A. Nadolski, Grunwald. Problemy wybrane, Olsztyn 1990, s. 113, 115. Dla porównania: armia Dunina w bitwie pod Świecinem (17 września 1462 r.) miała liczyć około 2 tys. żołnierzy. Siły krzyżackie szacowane są na 1400 zaciężnych i 1300 chłopów. Zob. Z. Spieralski, Wojskowość polska w okresie Odrodzenia, [w:] Zarys dziejów wojskowości polskiej do roku 1864, t. I: Do roku 1648, red. J. Sikorski, Warszawa 1965, s. 291-293; M. Biskup, Trzynastoletnia wojna z Zakonem Krzyżackim 1454-1466, Warszawa 1967, s. 623, 624; T.M. Nowak, J. Wimmer, Historia oręża polskiego 963-1795, Warszawa 1981, s. $259-260$. 
krycia raczej nie będzie zmianą jakościową. Zatem wydaje się, że jedynym rozwiązaniem możliwym do zastosowania na szerszą skalę jest ponowna reinterpretacja znanych już źródeł z wykorzystaniem nowej metodologii, poszukiwanie nowych możliwości, nie tyle w pozyskaniu nowej podstawy źródłowej, ile w zmianie dotychczasowej perspektywy badawczej, większa niż dotychczas „interdyscyplinaryzacja” badań, czerpanie z doświadczeń innych nauk. Wystarczy przypomnieć dokonania Tomasza Jasińskiego dotyczące odczytania na nowo zapisek Jana Długosza na temat bitwy pod Legnicą w 1241 roku $^{6}$.

Przemysław Urbańczyk pisał ostatnio: „Mimo forsowanego przez elity intelektualne zbliżenia archeologii i historii, które dokonuje się dzięki przekraczaniu tradycyjnych barier związanych z rodzajem wykorzystywanych źródeł i zakresem zainteresowań badawczych, inter- czy transdyscyplinarne badania dotyczące konkretnych problemów wciąż należą do rzadkości"”. W stwierdzeniu tym kryje się niestety wiele prawdy, jednak warto odnotować te inicjatywy, w ramach których postulowana inter- czy transdyscyplinarność ma już miejsce. Należy wspomnieć organizowane z inicjatywy Andrzeja Nadolskiego (a po jego śmierci przez Instytut Historii Kultury Materialnej Polskiej Akademii Nauk Oddział w Łodzi, a następnie Instytut Etnologii i Archeologii PAN Oddział w Łodzi) Międzynarodowe Kolokwia Bronioznawcze. Cyklicznie odbywające się spotkania bronioznawców reprezentujących przeróżne warsztaty badawcze (począwszy od archeologii, poprzez historię, historię sztuki, filologię klasyczna) przyniosły nie tylko istotne dla dziejów wojskowości opracowania stworzone w „koprodukcji”, ale także doprowadziły do współpracy głównie historyków i archeologów. Opracowania z cyklu „Uzbrojenie w Polsce średniowiecznej” czy „Polska

${ }^{6}$ T. Jasiński, Strategia i taktyka wojsk polskich i mongolskich pod Legnica w świetle nowo odczytanych zapisek Jana Dtugosza, [w:] Bitwa Legnicka - historia i tradycja, red. W. Korta, Wrocław 1994, passim; idem, Rozważania o wiarygodności przekazów źródtowych dotyczacych bitwy legnickiej, [w:] Bitwa z Mongotami na Dobrym Polu w 1241 rokumiejsce, tto, środowisko, relacje, red. K. Jaworska, Legnica 2011, passim.

7 P. Urbańczyk, Mieszko Pierwszy Tajemniczy, Toruń 2012, s. 20-21. Szerzej zob. Archaeologia versus historiam - historia versus archaeologiam, czyli jak wspólnie poznawać średniowiecze?, red. M. Brzostowicz, M. Przybył, D.A. Sikorski, Poznań 2012, szczególnie s. 79-97. 
technika wojskowa do 1500 roku” są dziś przecież uznawane za teksty wręcz „kanoniczne”. Nie znaczy to oczywiście, że są one wolne od błędów (choćby kwestia czasu funkcjonowania pewnych typów uzbrojenia czy możliwości transportowych taboru armii średniowiecznej) ${ }^{8}$, ale stanowią solidną podstawę do dalszych dociekań.

Warto również odnotować, że w ostatnim piętnastoleciu powstało kilka prac, poświęconych początkom broni palnej ${ }^{9}$. Brak jednak nowych opracowań, które podejmowałyby problematykę przedogniowej artylerii oblężniczej, a przykłady podobnych, nieobecnych w nowszej literaturze zagadnień, które wymagałby badań inter- i transdyscyplinarnych, można mnożyć. Tymczasem zasada przyświecająca tego rodzaju badaniom sprawdziła się wielokrotnie przy współpracy historyków wojskowości, historyków kultury materialnej i archeologów. Dość przypomnieć przywołane wyżej monografie wieloautorskie czy czasopismo w znacznej mierze poświęcone problemom związanym z dziejami wojskowymi, a szczególnie dziejami uzbrojenia pt. „Fasciculi Archaeologiae Historicae”. Należy także pamiętać o inicjatywach nowych, wśród których, jak pisał Leszek Kajzer, „najciekawszym periodykiem są bez wątpienia wydawane z inicjatywy Piotra Kotowicza „Acta Militaria Mediaevalia”"10.

Idąc tropem współpracy przedstawicieli różnych środowisk naukowych warto być może podjąć próbę zbadania motywacji psychologicznych dowódców, podejmujących decyzje w imieniu swoim, ale i swoich podwładnych. Wiadomo przecież, że tego typu badania prowadzono z perspektywy innych nauk; znane są publikacje $\mathrm{z}$ tego zakresu ${ }^{11}$. Skoro w ramach

${ }^{8}$ A. Nowakowski, Uzbrojenie indywidualne, [w:] Polska technika wojskowa do 1500 roku, red. A. Nadolski, Warszawa 1994, s. 247; idem, Sprzęt taborowy, obozowy i przeprawowy, [w:] ibidem, s. 255.

9 J. Szymczak, Początki broni palnej w Polsce (1383-1533), Łódź 2004; P. Strzyż, Średniowieczna broń palna $w$ Polsce. Studium archeologiczne, Łódź 2011; P. Chlebowicz, Ręczna broń palna w'redniowieczu (badania eksperymentalne), Chojnice-Toruń 2013.

${ }^{10}$ L. Kajzer, O meandrach polskiego bronioznawstwa stów kilka, [w:] „Broń zwierciadtem epoki”. Andrzeja Nadolskiego dokonania i inspiracje, red. P. Strzyż, W. Świętosławski, Łódź 2013, s. 17.

11 J. Borkowski, M. Dyrda, L. Kanarski, B. Rokicki, Stownik terminów z zakresu psychologii dowodzenia i zarzadzania, Warszawa 2000, The Psychological Assessment of Political Leaders with Profiles od Saddam Hussein and Bill Clinton, ed. J.M. Post, University of 
drugiej przywołanej pracy (The Psychological Assessment of Political Leaders with Profiles od Saddam Hussein and Bill Clinton, ed. J. M. Post, University of Michigan 2003) zdołano przeprowadzić studia z zakresu psychologii władzy, być może obiecującą możliwością byłyby badania nad psychologią dowodzenia w ujęciu historyczno-wojskowym. Zwłaszcza, że jak pisał Tomasz Pawelec: „szczyt wpływów i popularności psychohistorii niewątpliwie minął, to jest ona nadal żywym składnikiem współcześnie uprawianych badań historycznych"12. Odnoszę wrażenie, że na niwie badań historyczno-wojskowych, niestety, odczuwany jest brak tego typu kompleksowych opracowań. A przecież wielokrotnie podkreślano w literaturze przedmiotu nie tylko odmienność kulturową i cywilizacyjną średniowiecza i jego wojowników od czasów wspótczesnych, zwracano uwagę na potrzebę realizacji stereotypu bohaterskiego kombatanta, który dla sławy posuwa się do zachowań brawurowych, chce zyskać rozgłos, niejednokrotnie ryzykuje przegraną byle uniknąć oskarżenia o tchórzostwo. Jeszcze bardziej interesująca i inspirująca może być konfrontacja „nowego”, renesansowego rycerstwa ze średniowiecznym obyczajem rycerskim. Nie tylko forma organizacji wojska za panowania Jagiellonów doznała licznych przemian. Dotyczyły one również wojowników/rycerzy/żołnierzy, ale także ich statusu społecznego, począwszy od prostych strzelców w piechocie, wywodzących się głównie z mieszczaństwa, a skończywszy na szlachcie, która z upływem czasu przekształcała się w ziemiaństwo, zaś jej pozycja w państwie (defensor patriae) przechodziła $\mathrm{w}$ sferę symboliczną. To ostatnie zagadnienie zasługuje na osobne opracowanie.

Kolejnym polem, które dotychczas zazwyczaj było pomijane przez historyków wojskowości, są problemy życia codziennego i powszedniego (te dwie kategorie nie są tożsame) wojowników/rycerzy/żołnierzy. Obecnie niewiele wiadomo na temat tego, jakim zajęciom oddawał się rycerz lub żołnierz w domu, jak podróżował do punktu zbornego wojsk, w jaki sposób wracał z wojny i na koniec: jakie były warunki pojmanego w niewolę oraz jak los jeńca wojennego wpływał na byt jego rodziny. W piśmiennic-

Michigan 2003; T. Pawelec, Dzieje i nieświadomość. Zatożenia teoretyczne i praktyka badawcza psychohistorii, Katowice 2004, przykłady można mnożyć.

${ }_{12}$ T. Pawelec, Dzieje..., s. 10. 
twie ostatnich lat nieco szerzej naświetlono kwestie warunków życia wojowników stanu rycerskiego ${ }^{13}$. Dotyczy to również bytowania w obozach, przemarszach oraz w oblężonych umocnionych punktach oporu. Warto tu przypomnieć interesujące badania nad wojownikami służącymi z tytułu ius militare, jak również żołnierzami plebejskiego pochodzenia ${ }^{14}$.

Godną odnotowania jest inicjatywa łódzkiego ośrodka badawczego, który od czerwca 2017 roku organizuje cykl konferencji pod hasłem „Oblicza wojny" ${ }^{15}$. Tematyka poruszana podczas obrad dotyczyła właśnie kwestii przemieszczenia wojska w każdym jego aspekcie (począwszy od spraw organizacyjnych, topograficznych, a skończywszy na warunkach życia w obozie i przemarszu). Drugie spotkanie skupiło się wyłącznie na sprawach bytowania żołnierzy w szeroko rozumianym obozie wojskowym i garnizonach. Trzecie z kolei, na szeroko rozumianej percepcji wojska w źródłach, ze szczególnym naciskiem położonym na sprawy wzorców osobowych, zachowań i ogólnie pojętego dnia powszedniego żołnierzy. Nietrudno powiązać ten cykl spotkań z ostatnimi publikacjami łódzkiego badacza, Jana Szymczaka, który w 2016 roku rozpoczął swój cykl publikacji poświęconych rycerzom $^{16}$. Dwa już opublikowane tomy są początkiem szerszego cyklu, który ma być poświęcony między innymi jeszcze wierzchowcom, podróżowaniu, czy obozom rycerskim.

Wreszcie należałoby postawić pytanie, jak przebiegało życie cywilów, czy może raczej „nie-wojowników” w trakcie toczących się walk. Znany jest przecież anegdotyczny wręcz opis dotyczący kmieci wdrapujących się na drzewa w trakcie bitwy grunwaldzkiej, dla uzyskania lepszego widoku

${ }^{13}$ Zob. choćby L. Kajzer, Zamki i dwory obronne w Polsce Centralnej, Warszawa 2004.

${ }^{14}$ J. Szymczak, Pojedynki i harce, turnieje i gonitwy. Walki o życie, cześć, stawe i pieniądze $w$ Polsce Piastów i Jagiellonów, Warszawa 2008; idem, Żywność na miejskich wozach wojennych w późnym średniowieczu i na początku epoki nowożytnej, „Przegląd Nauk Historycznych" 2006, R. 5, nr 1 (9), s. 59-74.

15 Spotkanie inauguracyjne odbyło się 1 czerwca 2017 r. Poświęcone było „Wojsku w drodze”. Kolejne miało miejsce w dniach 16-17 listopada 2017 r. („W koszarach i obozie”), trzecie zaś 7-8 czerwca 2018 r. („Ludzie wojny”).

${ }^{16}$ J. Szymczak, Rycerz $w$ hetmie, w zbroi i z tarcza, Warszawa 2016; idem, Rycerz z bronia zaczepna, Warszawa 2017. 
na pole walki. Jednak sprowadzanie życia „nie-wojowników” na obszarze objętym działaniami zbrojnymi do takiego obrazu jest znacznym uproszczeniem. Traktowanie bitwy jako swoistej atrakcji zapewne mogło mieć miejsce, lecz z pewnością przemarsz wojsk, bitwa i oblężenie wiązały się przede wszystkim z ogromnym zagrożeniem egzystencjalnym dla lokalnej ludności. Odnotowywane w źródłach masowe ucieczki przed nadciągającą armią, lub roszczenia wysuwane przez ludność niezaangażowaną bezpośrednio w działania zbrojne pod adresem żołnierzy, którzy w ramach tak zwanego picowania dokonywali spustoszenia okolicy, nie należały przecież do rzadkości.

Warto także wspomnieć o tak zwanej motywacji żołnierzy do walki. Motywacja, która jest przecież kategorią psychologiczną, jest kolejnym problemem badawczym, który nie został zbyt dobrze rozpoznany. Jednocześnie zarówno rycerze, jak i żołnierze pieniężni, wstępując w szeregi wojska, kierowali się różnorodnymi motywacjami ${ }^{17}$. Charakter źródeł powoduje, że niełatwo określić, czy służba wojskowa była intratnym zajęciem, czy niebezpieczną, bo grożącą niewolą, kalectwem lub śmiercią koniecznością, pozwalającą znaleźć zatrudnienie i pozyskanie - dziś powiedzielibyśmy - minimum socjalno-bytowego? Dość jeszcze raz odwołać się do przykładu wojny trzynastoletniej i przypomnieć postać jednego z dowódców zaciężnych krzyżackich - Oldrzicha Czerwonki. Jakimi pobudkami kierował się ten żołnierz, skoro podjął ryzyko negocjacji z nieprzyjacielem (to znaczy wojskami Kazimierza Jagiellończyka) w sprawie zapłaty zaległości żołdowych, przekazania zamku malborskiego w ręce swych niedawnych wrogów oraz przejścia do nich na służbę? Oldrzych Czerwonka jest tu oczywiście symbolem „nowego” w polskiej średniowiecznej sztuce wojennej. Przykładem wręcz „pracownika najemnego”, który walczy już nie dla idei (jak chciały romanse rycerskie) czy dla swego suwerena (jak chciał obyczaj prawny). Jak zatem przebiegała zmiana; zastępowanie dawnych obyczajów wojskowych

17 Zob. choćby T. Grabarczyk, Piechota zaciężna Królestwa Polskiego w XV wieku, Łódź 2000; idem, Jazda zaciężna Królestwa Polskiego w XV wieku, Łódź 2015; A. Bołdyrew, Między koniecznościa a powinnościa. Motywacje podejmowania stużby w XVI-wiecznej zaciężnej armii koronnej, [w:] O powinnościach żotnierskich, t. I: Na fundamencie historii i tradycji, red. A. Drzewiecki, Oświęcim 2016. 
nowymi? Czy były one już zapowiedzią renesansowych form organizacji wojska? I w jakim stopniu proces ten był zauważany przez ówczesnych? Znalezienie odpowiedzi na te pytania z pewnością uzupełniłoby spektrum wiedzy na temat wojskowości jagiellońskiej, miałoby szansę stać się wartością dodaną w badaniach historyczno-wojskowych.

Nie można pominąć również faktu, że w przypadku okresu panowania ostatnich Jagiellonów na polskim tronie (1501-1572) mamy do czynienia z o wiele lepiej zachowaną archiwalną podstawą źródłową, co nie znaczy, że jest ona kompletna. I tak na przykład brak szczegółowych danych źródłowych dotyczących choćby znanej wyprawy wojsk litewskich i polskich pod Orszę w 1514 roku. Opublikowana w 2000 roku popularna praca na temat bitwy orszańskiej, autorstwa Piotra Dróżdża, była w zasadzie pierwszą próbą nieco szerszego ujęcia tematu ${ }^{18}$. W głównej mierze bazowała na dotychczasowych ustaleniach i miała wąską podstawę źródłową. Nie można jednak zapominać, że taki też jest wymóg serii, w ramach której opublikowano pracę (seria „Historyczne Bitwy”). Zupełnie inaczej przedstawia się to w przypadku rocznicowego wydawnictwa, a mianowicie jednego z tomów „Biblioteki Epoki Nowożytnej”, poświęconego bitwie pod Orszą ${ }^{19}$. Dwunastu autorów z Polski, Białorusi i Ukrainy w oparciu o szeroką podstawę źródłową podjęło zagadnienie samej bitwy, jak również kwestie około bitewne. Wyraźnie widoczna jest tu zmiana, o której wspominałem wcześniej. Szeroki wybór tematów, nowe teorie związane choćby z lokalizacją miejsca bitwy czynią z tomu wydawnictwo wyraźnie odbiegające od tradycyjnego, socjomasowego spojrzenia na dzieje wojskowe.

Ogólne możliwości badawcze w odniesieniu do epoki renesansu są diametralnie odmienne w zestawieniu ze średniowieczem. I choć ustalenia czy choćby hipotezy, opierane są nie tylko na przekazach narracyjnych, ale także na stosunkowo nieźle zachowanych materiałach wojskowo-gospodarczych, to dorobek w tym zakresie nie jest tak obfity jak w przypadku klasycznie rozumianego średniowiecza. Ten szeroki zespół głównie archiwaliów był jak dotąd przedmiotem jedynie dość wybiórczych analiz, poświęconych głównie jednej kampanii. Dobrym przykładem jest choćby mono-

${ }^{18}$ P. Dróżdż, Orsza 1514, Warszawa 2000.

19 „Biblioteka Epoki Nowożytnej” 2015, R. 2: Bitwa pod Orszą, red. M. Nagielski. 
grafia Zdzisława Spieralskiego z 1962 roku $^{20}$. Monografia ta w zasadniczym zrębie jest aktualna do dziś.

Należy również odnotować dokonania innych badaczy, w tym Marka Plewczyńskiego, który podjął nie tylko zagadnienia czysto militarne ${ }^{21}$, ale również dużo uwagi poświęcił sprawom przynależności etnicznej i społecznej żołnierzy służących za polskie pieniądze, ich obyczajowi wojskowemu czy pochodzeniu terytorialnemu ${ }^{22}$. Zajmował się także problemem uzawodowienia służby wojskowej ${ }^{23}$. Zupełnie osobne miejsce zajmuje trzytomowe dzieło poświęcone wojnom i wojskowości polskiej w XVI wieku ${ }^{24}$. To quasi podręcznikowe ujęcie stanowić może doskonałe wprowadzenie do tematu, swoisty przewodnik wiodący poprzez najważniejsze kwestie związane z wojskowością Polski renesansowej. Jednocześnie trzeba zaznaczyć, że dzieło to podsumowując dotychczasowy (do około 2013 roku) stan badań nie porusza (bo i nie może w tej formie poruszyć) wielu zagadnień szczegółowych, jak dotąd niezbadanych.

Podkreślenia wymaga fakt, że przywołanie tych dokonań badawczych nie ma na celu wskazywania mankamentów prac mediewistów. Chodzi przede wszystkim o wskazanie różnicy w zachowanym zasobie źródłowym, który w dużym stopniu determinuje kształt badań nad przeszłością. Paradoksalnie, pewne kwestie gorzej znane ze źródeł, doczekały się monumentalnych monografii, natomiast inne, doskonale „umocowane” źródłowo - nie. Mam na myśli przede wszystkim dzieło Sławomira Jóźwiaka, Krzysztofa Kwiatkowskiego, Adama Szwedy i Sobiesława Szybkowskiego ${ }^{25}$. Imponująca kwerenda źródłowa i literaturoznawcza, w oparciu o którą po-

20 Z. Spieralski, Kampania obertyńska 1531 roku, Warszawa 1962.

${ }^{21}$ M. Plewczyński, Obertyn 1531, wyd. 1, Warszawa 1994; idem, Wojny Jagiellonów z wschodnimi i potudniowymi sasiadami Królestwa Polskiego w XV wieku, Siedlce 2002.

${ }^{22}$ Idem, W stużbie polskiego króla. $Z$ zagadnień struktury narodowościowej Armii Koronnej w latach 1500-1574, wyd. 1, Siedlce 1995.

${ }^{23}$ Idem, Zotnierz jazdy obrony potocznej za czasów Zygmunta Augusta. Studia nad zawodem wojskowym $w$ XVI w., Warszawa 1985.

${ }^{24}$ Idem, Wojny i wojskowość polska $w$ XVI wieku, t. 1: Lata 1500-1548, wyd. 1, Zabrze 2011, t. 2: Lata 1548-1575, wyd. 1, Zabrze 2012, t. 3: Lata 1576-1599, wyd. 1, Zabrze 2013.

${ }^{25}$ S. Jóźwiak, K. Kwiatkowski, A. Szweda, S. Szybkowski, Wojna Polski i Litwy z Zakonem Krzyżackim w latach 1409-1411, Malbork 2010. 
wstała praca, wyznacza zupełnie nowy poziom możliwości badawczych. $\mathrm{Z}$ prac starszych warto $\mathrm{w}$ tym miejscu przypomnieć również dzieła Mariana Biskupa: kompleksowe opracowanie dziejów wojny trzynastoletniej (1454-1466) oraz tak zwanej „wojny pruskiej” (1519-1521) ${ }^{26}$. Co więcej, monografia „wojny pruskiej” jest jednym z dwóch tomów poświęconych zagadnieniu sekularyzacji Prus Krzyżackich ${ }^{27}$.

Pomijając wymienione wyżej prace Z. Spieralskiego czy M. Plewczyńskiego, dokonania historyków wojskowości renesansowej w zakresie monografii dotyczących organizacji dziejów poszczególnych rodzajów broni, dziejów wojen czy szeroko rozumianej techniki wojskowej (z wyłączeniem większości dzieł Tadeusza Mariana Nowaka) nie są, niestety, imponujące. Nieco lepiej wygląda sytuacja dziejów formacji wojskowych ${ }^{28}$. Warto w tym miejscu przypomnieć opracowania Karola Łopateckiego, które w perspektywie długiego trwania podejmują problem organizacji, prawa i dyscypliny armii polskiej i litewskiej ${ }^{29}$. Prócz wspomnianej monografii Z. Spieralskiego (w zakresie dziejów wojen), w zasadzie brak jest innej tego typu pracy. Pozostałe kampanie wojenne oraz rodzaje broni nie doczekały się analitycznego omówienia. Oczywiście można uznać, że żadna z wojen prowadzonych przez Polskę w pierwszych trzech ćwierćwieczach XVI wieku nie zagrażała

${ }^{26}$ M. Biskup, Trzynastoletnia...; idem, „Wojna pruska”, czyli wojna Polski z Zakonem Krzyżackim z lat 1519-1521. U źródet sekularyzacji Prus Krzyżackich, cz. 2, Olsztyn 1991.

${ }^{27}$ Idem, Polska a Zakon Krzyżacki w Prusach w początkach XVI wieku. U źródet sekularyzacji Prus Krzyżackich, Olsztyn 1983.

${ }^{28}$ Dla porządku można przywołać jeszcze: A. Bołdyrew, Polska piechota zaciężna w Polsce w pierwszej potowie XVI wieku, Warszawa 2011; G. Lesmaitis, Wojsko zacięzne $w$ Wielkim Księstwie Litewskim w końcu XV-drugiej potowie XVI wieku, Warszawa 2013; P. Borawski, Ziemska stużba wojskowa Tatarów Wielkiego Księstwa Litewskiego w XV-XVII wieku, Zabrze 2015; B. Głubisz, Jazda kozacka w armii koronnej 1549-1696, Poznań 2016; poniekąd również D. Kupisz, Wojska powiatowe samorzadu Matopolski i Rusi Czerwonej w latach 1572-1717, Lublin 2008. Tymczasem na przykład zarówno piechota, jak i jazda zaciężna Królestwa Polskiego w XV w. doczekały się swych szczegółowych i niezwykle kompetentnych opracowań, zob. T. Grabarczyk, Piechota...; idem, Jazda.... Warto także przywołać monumentalne dzieło K. Kwiatkowskiego, Wojska zakonu niemieckiego w Prusach 1230-1525, Toruń 2016.

${ }^{29} \mathrm{~K}$. Łopatecki, „Disciplina militaris” w wojskach Rzeczypospolitej do potowy XVII wieku, Białystok 2012; idem, Organizacja, prawo i dyscyplina w polskim i litewskim pospolitym ruszeniu (do potowy XVII wieku), Białystok 2013. 
bezpośrednio bytowi państwa polskiego, toteż i znaczenie tych kampanii jest niepomiernie mniejsze, niż na przykład kampanii letniej 1410 roku, jednak fakt zachowania szeroko rozumianych materiałów źródłowych powinien skłonić do pochylenia się nad nimi. Wyrażałem już opinię, że brak spektakularnej batalii zniechęca do podjęcia zagadnienia wyprawy wojennej. Nie znaczy to jednak, że marginalizowanie problemu jest adekwatne do znaczenia pewnych wydarzeń w przeszłości ${ }^{30}$.

Dlatego też formą zarysowania istotnej kampanii wojennej, choćby z punktu widzenia liczebności zgromadzonych wojsk, jest planowana publikacja materiałów źródłowych związanych z wyprawą letnią hetmana Jana Tarnowskiego do Mołdawii w 1538 roku. Publikacja ma być efektem tak zwanego „grantu jagiellońskiego” („Epoka jagiellońska i jej dziedzictwo w I Rzeczypospolitej do 1795 roku. Źródła do dziejów wojskowości polskiej w epoce Jagiellonów”) ${ }^{31}$. Jeden z podzespołów badawczych przygotowuje krytyczne wydanie akt skarbowo-wojskowych armii koronnej biorącej udział w wyprawie pod Chocim. Trzeba zaznaczyć, że tego typu publikacja ukazała się, i to w dość skromnej formie, w $1958 \mathrm{roku}^{32}$, a zatem ponad pół wieku temu. Dopiero po skrupulatnym opracowaniu zespołu zachowanych źródeł, możliwe będzie stworzenie kompletnej (źródłowo) monografii samej kampanii.

Godnym namysłu zagadnieniem jest problem uwzględnienia techniki wojskowej $\mathrm{w}$ pracach historyczno-wojskowych. Jak wspominałem wcześniej, liczne prace T.M. Nowaka, których początek można datować na 1955 rok $^{33}$, znacznie poszerzyły wiedzę na temat artylerii, techniki przeprawowej i oblężniczej. Nie zmienia to faktu, że nadal brak opracowania dotyczącego artylerii polskiej, szczególnie zaś po 1533 roku. Jeśli chodzi o inne elementy techniki wojskowej, a już szczególnie uzbrojenia, to w tym

30 A. Bołdyrew, Hand Fire-arms of the Polish Mercenary Infantry During the Moldavian Campaign of 1538, „Fasciculi Archaeologiae Historicae” 2012, fasc. XXV, s. 59.

31 Grant Ministra Nauki i Szkolnictwa Wyższego w ramach Narodowego Programu Rozwoju Humanistyki (Nr 0469/NPRH5/H30/84/2017) pod kierownictwem prof. dra hab. Jana Szymczaka.

32 Wypisy do źródtowe do historii polskiej sztuki wojennej, z. 4: Polska sztuka wojenna w latach 1454-1562, oprac. Z. Spieralski, Warszawa 1958.

33 T. Nowak, Polska sztuka wojenna w czasach odrodzenia, Warszawa 1955. 
przypadku jest nieco lepiej, choć większość rozpraw jest jedynie przyczynkami. Jak wspominałem wcześniej, bronioznawstwo średniowieczne rozwija się dynamicznie, dzięki współpracy archeologów i historyków. Niestety, z niewielkimi wyjątkami ${ }^{34}$, nie można tego powiedzieć o dziejach uzbrojenia wczesnonowożytnego. W tym obszarze trudno mówić o zaawansowanej współpracy, natomiast opracowania historyków, oparte w głównej mierze na źródłach pisanych, dają pewne wyobrażenie o kategoriach ilościowych, rzadziej jakościowych ${ }^{35}$. W tym właśnie miejscu widziałbym perspektywy badań interdyscyplinarnych.

Tak zarysowany szeroki horyzont badawczy powinien, moim zdaniem, zaowocować rozpisaniem nowego projektu mającego na celu opublikowanie wieloautorskiej monografii poświęconej historii wojskowości (od początku państwa polskiego do końca epoki jagiellońskiej), szczególnie mocno skupionej na polskich dziejach wojskowych na szerokim tle środkowoeuropejskim. Szczególną uwagę należy skupić na problemach otaczających wojnę, które były przecież nie tylko tłem działań zbrojnych, ale w dużej mierze również ich podstawą, czynnikiem towarzyszącym dokonaniom armii, dowódców i wreszcie poszczególnych wojowników. Trud ten opłacił się w przypadku nowych serii podręczników akademickich historii Polski, w których szczególną uwagę poświęcono po raz pierwszy w historiografii dziejom cywilizacji ${ }^{36}$. Zabieg ten w pewnym stopniu podniósł do rangi poważnego tematu badawczego zagadnienia do tej pory w oficjalnej wykładni akademickiej marginalizowane. Mam na myśli dzieje zwykłych ludzi, ich życie prywatne, codzienną egzystencję i jej warunki. Wartościowym krokiem w tym kierunku było poświęcenie uwagi zagadnieniom związanym z biologiczną egzystencją człowieka w średniowieczu podczas III Kongresu Mediewistycznego, który odbył się w Łodzi we wrześniu 2008 roku.

Myślę, że wyzwaniem najbliższych lat powinno stać się napisanie nowej syntezy/podręcznika historii wojskowości epoki Piastów i Jagiellonów,

${ }_{34}$ Zob. choćby M. Cieśla, Broń renesansowa na Śląku, Racibórz 2008; L. Marek, Średniowieczne uzbrojenie Europy tacińskiej jako Ars Emblematica, Wrocław 2017.

35 A. Bołdyrew, Produkcja i koszty uzbrojenia w Polsce XVI wieku, Warszawa 2005.

36 S. Szczur, Historia Polski: średniowiecze, Kraków 2002; M. Markiewicz, Historia Polski: 1492-1795, Kraków 2004; T. Jurek, E. Kizik, Historia Polski do 1572, Warszawa 2013. 
którego optyka byłaby skierowana nie tylko na przebieg działań zbrojnych czy kwestie organizacyjne siły zbrojnej. Znaczącym wsparciem byłyby na przykład coraz liczniejsze badania prozopograficzne. Możliwość czerpania z tych ustaleń pomogłaby uporządkować rozproszoną wiedzę na temat ludzi wojny, lecz nie tylko w odniesieniu do postaci kluczowych, pierwszoplanowych. Nowe ustalenia rozproszone po wielu publikacjach nie zawsze mają wpływ na zmianę tradycyjnego obrazu polskiej armii piastowskiej i jagiellońskiej. Dopiero dane zgromadzone w jednym miejscu pozwolą w pełni ocenić dotychczasowe dokonania, ale i wyznaczyć szczegółowe kierunki dalszych dociekań. W ten sposób być może udałoby się doprowadzić do mariażu optyki badań mentalnościowych zapoczątkowanych przez środowisko Annales i kwestii uwarunkowań społeczno-gospodarczych oraz motywacji postępowania coraz lepiej znanych wodzów i wojowników.

Konkludując, warto raz jeszcze zwrócić uwagę na możliwości rozszerzenia perspektyw badań historyczno-wojskowych epoki Piastów i Jagiellonów, które związane są z wykorzystaniem namysłu interdyscyplinarnego oraz pogłębieniem refleksji teoretycznych i metodologicznych. Propagowany we współczesnej nauce pluralizm podstaw metodologicznych jest koniecznością również w obszarze badań nad historią wojskowości. Wykorzystanie rzadko stosowanych dotychczas metod, strategii i narzędzi może umożliwić podjęcie tematów dotychczas zaledwie sygnalizowanych lub nieobecnych. Stwarza to także nowe możliwości w zakresie treści, metod, celów i środków popularyzacji wśród szerokiego grona odbiorców wyników prac historyków. 